\title{
Construcciones identitarias y sentidos de pertenencia en el espacio surandino al finalizar la guerra de independencia. Salta (Argentina) y Bolivia entre 1824 y $1826 \%$
}

\section{Identity Constructions and Senses of Belonging in the South Andean Space after the War of Independence. Salta (Argentina) and Bolivia between 1824 and 1826}

\author{
Telma Liliana Chaile \\ ORCID iD: http://orcid.org/0000-0003-2204-8614 \\ María Mercedes Quiñonez \\ ORCID iD: http://orcid.org/0000-0002-9055-6066 \\ ICSOH-CONICET, CEPIHA-UNSa, Argentina
}

Nos proponemos analizar los procesos de construcción identitaria en el espacio surandino en el interregno 1824-1826, etapa de gestación de fronteras estatales. Se considerarán los casos de Salta y Bolivia en la conformación de la frontera para examinar las marcas identitarias emergentes en la construcción discursiva de las diferencias por parte de algunos actores de las elites locales.

Palabras Clave: Construcciones Identitarias; Salta; Bolivia; Fronteras; Década de 1820.

We propose to analyze the processes of identity construction in the southern Andes, in the interregnum 1824-1826, during which state borders are gestated. The cases of Salta and Bolivia will be considered in the conformation of the border to examine emerging identity marks on the discursive construction of the differences by some actors of the local elites.

Keywords: Identities Constructions; Salta; Bolivia; Borders; 1820s Decade.

Copyright: (C) 2017 CSIC. Este es un artículo de acceso abierto distribuido bajo los términos de una licencia de uso y distribución Creative Commons Attribution (CC-by) España 3.0.

* Forma parte de los Proyectos CIUNSA 2249/1 y PIP CONICET 0112. Agradecemos las valiosas sugerencias de los evaluadores anónimos. 


\section{Introducción}

Desde las últimas décadas del siglo XX varios trabajos han abordado de manera renovada el estudio de la conformación de los estados nacionales en Hispanoamérica durante la centuria decimonónica, proceso desatado a partir de la crisis monárquica y resultante de un período de guerras que se inició en el decenio de 1810. ${ }^{1}$ Tempranamente la cuestión territorial se tornó significativa a medida que distintos colectivos reclamaron derechos sobre el territorio que habitaban y sobre el cual aspiraban a ejercer el poder. ${ }^{2} \mathrm{El}$ ejercicio de la soberanía, las guerras y los reordenamientos jurisdiccionales desdibujaron las divisiones administrativas coloniales y en el caso del Río de la Plata dieron origen a la conformación de las provincias como entidades soberanas. ${ }^{3}$ En este contexto de cambios, los sujetos no dejaron de elaborar sentidos de pertenencia en relación a una o más comunidades en particular.

José Carlos Chiaramonte señaló la coexistencia de tres formas de identidad política hacia 1810 en el espacio rioplatense: una identidad hispanoamericana como prolongación de lo español americano en tanto diferenciación a escala imperial; otra identidad definida como provincial «asentada en el sentimiento lugareño», y la identidad rioplatense o porteña que irá adquiriendo la denominación de «argentina». Se trata de una coexistencia que tiene significatividad al considerarlas como «formas alternativas de satisfacer la necesidad de organizar un nuevo estado que suplantase al dominio hispano». ${ }^{4}$ La producción historiográfica posterior ha dado cuenta de la emergencia de identidades sociales y políticas durante esa primera mitad del siglo XIX a partir de la guerra de independencia y el surgimiento de las provincias como estados independientes luego de la caída del Directorio (1820). ${ }^{5}$

1 Chiaramonte, 1991 y 1995. Guerra, 1995. Goldman y Souto, 1997. Goldman, 1998. En Buenos Aires, capital del virreinato del Río de la Plata, se desconoció al Consejo de Regencia, lo que dio lugar a la conformación de una junta de gobierno en nombre de Fernando VII. Las nuevas autoridades invitaron a los cabildos de las ciudades que integraban el virreinato a enviar diputados para su incorporación a la junta. Con posterioridad se sucedieron gobiernos centralizados: el Triunvirato (1811-1814) y el Directorio (1814-1820). Goldman y Souto, 1997, 27-28. Goldman, 1998, 41-42, 45-46.

2 Ternavasio, 2009, 10-11.

3 Chiaramonte, 1995, 167. Guerra, 1995, 209.

4 Chiaramonte, 1989,71-72.

5 Bragoni y Mata, 2007. Rabinovich, 2009. Marchionni, 2011. Amadori y Di Pasquale, 2013. Peire, 2013a. Aun cuando las provincias «no eran parte de un Estado superior a ellas», conservaron la denominación por la vigencia de la tradición administrativa española y «la fugaz calidad de provincias propiamente dichas que les otorgaban los breves lapsos de existencia de gobiernos centrales rioplatenses, tales como el Directorio [1814-1820] o la presidencia de Rivadavia [1826-1827]». Chiaramonte, $1995,167$. 
Hacer foco en los espacios provinciales que resultaron fronteras políticas con otros estados nacionales puede contribuir a la reflexión sobre algunos de los derroteros posibles en la conformación de las autorreferencialidades locales y en la articulación de estos procesos con otros colectivos supraprovinciales.

En este escrito analizaremos los procesos de construcciones identitarias en el espacio surandino en el contexto de las relaciones entre la provincia de Salta y la República de Bolivia creada en $1825 .{ }^{6}$ En ambos espacios, sectores de las elites invocaron denominaciones para los habitantes de estos territorios que estaban conformándose en soberanos durante la década de 1820 , por lo que es un objetivo de este estudio indagar en los sentidos de pertenencia respecto a estas comunidades políticas. Los gentilicios abaje$\tilde{n}$ os, argentinos, altoperuanos y bolivianos remiten a referencias identitarias, de allí la importancia de historizar estas identidades para determinar los «contextos [en los que] se activan o no ciertas marcas». ${ }^{7}$ Una aproximación a la temática será a partir de ubicar algunas líneas de análisis en torno a las cuestiones identitarias y los vínculos que otorgaban pertenencia a las comunidades abrevando en los planteos generales de los aportes historiográficos de las últimas décadas. Luego consideraremos los casos de Salta y Bolivia en la conformación de la frontera para analizar las marcas identitarias emergentes en la construcción discursiva de las diferencias por parte de algunos actores de las elites locales. La indagación comprenderá el interregno 1824-1826, coincidente con la culminación de la guerra de independencia, la diferenciación política y jurisdiccional gestada entre Salta y los territorios del Alto Perú a partir de la conformación del estado de Bolivia, ${ }^{8}$ y el inicio del faccionalismo político de alcances regionales. ${ }^{9}$ Las representaciones de quienes tuvieron participación en la arena política acerca de la situación de Salta y de Bolivia se hicieron manifiestas en relación a las otras provincias argentinas y a Buenos Aires, también entre la provincia salteña y la nueva república. Se trata de una coyuntura interesante por las

6 Antes y después del período de estudio, el noroeste de los territorios que conformarán la Argentina, sobre todo Jujuy y Salta, y el suroeste de Bolivia estuvieron vinculados por lazos culturales, económicos, poblacionales y familiares, los cuales hacen inteligible su pertenencia a un espacio que la historiografía regional reconoce como surandino o Andes meridionales. Mata, 2001, 138-143. Conti, 2011,16 .

7 Briones, 2007, 78.

8 Durante la reorganización administrativa colonial borbónica, la jurisdicción de Charcas pasó a depender del Virreinato del Río de la Plata con la denominación de Alto Perú. Mata y Figueroa, 2005, 131.

9 Mata y Figueroa, 2005. Marchionni, 2013. 
expresiones de pertenencia que aparecen asociadas a las configuraciones territoriales y a los proyectos de integración a comunidades políticas que se encontraban en formación.

\section{Vínculos y pertenencias en la conformación de la provincia de Salta}

La comunidad local nucleada en torno a la ciudad, que otorgaba rasgos de identificación y de pertenencia en la época colonial, se vio redefinida en clave política a partir de la revolución de independencia. Fue en ese sentido político que lo local reclamó autonomía, resignificando las múltiples identidades construidas en el período colonial. ${ }^{10}$ Se trata de un sentimiento lugareño colectivo, fortalecido luego del fracaso de los intentos constitucionalistas y de unidad en las Provincias del Río de la Plata, ${ }^{11}$ que asumió una forma política al proyectar un «manejo autónomo del poder». ${ }^{12}$ Este pasaje se advierte también en la conformación de grupos y redes familiares y de poder. En Salta a fines del siglo XVIII prevalecían — aunque no exentas de conflictos - redes sociales conformadas desde solidaridades basadas en el parentesco, la amistad, el paisanaje, combinadas con los lazos forjados a partir de la participación en los mismos circuitos mercantiles, que a su vez se cimentaban en vínculos personales. Desde la creación de la Intendencia de Salta del Tucumán, la ciudad de Salta recibió la afluencia de funcionarios enviados por la Corona, los cuales constituyeron un factor que dinamizaba y complejizaba el espacio social local. Las reformas administrativas derivadas de este proceso impactaron al interior de la elite plasmando diferencias previas y conflictos nuevos en el marco de la lucha por las atribuciones y jurisdicción de la intendencia y los distintos cabildos. ${ }^{13}$ El espacio económico también sintió el impacto del proceso de mercantilización, producto entre otras cuestiones del ascenso comercial del puerto de Buenos Aires y de la recuperación de la minería peruana y altoperuana. La ciudad —eje de tres circuitos comerciales, de los cuales el más importante unía Buenos Aires con el Perú, articulando un comercio de gran escala— ${ }^{14}$ asistió a una

10 Guerra, 1995, 214-228.

11 Chiaramonte, 1989, 78, 89. Esos intentos comprendieron a la Asamblea General Constituyente (1813-1815) y al Congreso Constituyente (1816-1820). Durante este período se declaró la independencia de las Provincias del Río de la Plata (1816) y se proclamó una constitución unitaria que fue rechazada por las provincias (1819). Goldman y Souto, 1997, 38.

12 Chiaramonte, 1989, 89.

13 Marchionni, 1997. Mata, 2005. Quiñonez, 2009, 4-5.

14 Mata, 2005. 
reactivación económica y un crecimiento poblacional que se expresó por un mayor flujo comercial. A raíz de este impulso mercantil arribó a la ciudad de Salta un importante número de comerciantes peninsulares y de otras regiones del virreinato, ${ }^{15}$ quienes fueron protagonistas de un proceso de ascenso social ya que, si bien no detentaban linaje, prestigio social y poder como las familias tradicionales, lograron acumular riquezas a través de sus actividades económicas y las redes sociales que construyeron. ${ }^{16}$ Por su parte, la elite salteña debió adecuarse a la dinámica de la actividad económica y buscó alianzas con el sector de comerciantes, a fin de unir riqueza y linaje y permanecer en la cúspide de la jerarquía social. ${ }^{17}$

La coyuntura abierta en 1810 fracturó algunas de esas alianzas y las redefinió, incluso a nivel familiar. La participación de integrantes de una misma familia en bandos opuestos, la alineación de los miembros en los diferentes conflictos, las rupturas generacionales, permiten observar una lógica en la cual lo político aparece como parte de las relaciones y lazos que vinculan a los individuos, sumándose y superponiéndose a otros vínculos de tipo familiar, religioso o comercial, en una compleja trama de intereses y oportunidades. ${ }^{18}$ Con la ruptura revolucionaria los alineamientos políticos comenzaron a prevalecer frente a las lealtades familiares. ${ }^{19}$ Los miembros de la elite local debieron optar rápidamente por el bando revolucionario o realista. Los estancieros y hacendados locales apoyaron el pronunciamiento de la Junta de Buenos Aires y esto quedó expresado en la composición del cabildo local. Marcelo Marchionni sostiene que a partir de 1810 los principales comerciantes peninsulares que habían tenido destacada actuación en el cabildo desaparecieron de los cargos capitulares, ${ }^{20}$ quedando el cabildo en manos de los propietarios de tierras y los sectores más vinculados a ellos. Teniendo en cuenta enfrentamientos anteriores, el autor afirma que «la revolución significó la consolidación de las familias tradicionales de propietarios de tierras que se habían encolumnado en la defensa de las prerrogativas del Cabildo», ${ }^{21}$ a los que se sumaron los comerciantes que

15 Mata, 1993.

16 Quiñonez, 2009, 5.

17 Quiñonez, 2010.

18 Quiñonez, 2009, 17.

19 Para el caso salteño, se indagaron en otros trabajos los derroteros de algunos grupos familiares durante el proceso revolucionario, a partir de la reconstrucción de redes y alianzas forjadas en el período finicolonial y que se reestructuraron con la revolución. Los casos estudiados refieren a familias de la elite local como los Ruiz Gauna, Costas, Uriburu y Figueroa. Quiñonez, 2010 y 2012.

20 Marchionni, 1999, 193.

21 Ibidem, 194. 
adhirieron a la revolución. Sin embargo, el sector realista tendrá en Salta una importante presencia, que tiene relación con el apoyo brindado por parte de la elite local a los funcionarios borbónicos. ${ }^{22}$ Este «partido realista» aseguró la adhesión a la causa del rey, articulando mecanismos para el sostén del ejército o la presencia de los jefes militares en la ciudad. ${ }^{23}$ Los nuevos vínculos implicaron nuevas figuras identitarias y la guerra desorganizó las pertenencias espaciales de quienes estuvieron involucrados en el conflicto. ${ }^{24}$ En el caso de la familia Costas resulta interesante analizar cómo impactó la guerra y la conformación progresiva de fronteras estatales al interior de grupos de la elite local con vínculos familiares y comerciales que exceden el espacio local. ${ }^{25}$ Los miembros de esta familia se dispersaron a raíz de sus actividades comerciales y profesionales por distintas ciudades del virreinato, particularmente los varones, permaneciendo las mujeres en tierra salteña. Iniciado el proceso revolucionario, la familia Costas integraba el «partido realista», mientras que otra rama familiar - los Ruiz Gauna - se adhirieron a la causa revolucionaria. La figura central de la red familiar Costas era Francisco Avelino y la integraban dos de sus hermanos: Juan Manuel, exiliado en Puno desde 1819 donde falleció sin regresar a Salta, ${ }^{26}$ y Santiago, deán de la catedral de Potosí. ${ }^{27}$ También formaban parte de la red tres de sus cuñados: Rafael de Echenique, casado con Francisca, ${ }^{28}$ Juan Antonio de Murúa, casado con Manuela Antonia, ${ }^{29}$ y Agustín de Gasteaburu, casado con Liberata. Otro integrante fue Rafael Peró, quien llegó al Callao en 1816 para combatir en los ejércitos reales y al finalizar la guerra se avecindó en Salta y contrajo matrimonio con Josefa Costas Frías, hija de Francisco Avelino. ${ }^{30} \mathrm{El}$ entramado de la red familiar tejida por Avelino se

22 Mata, 2004, 232. Quiñonez, 2009, 17.

23 Quiñonez, 2010.

24 González Bernaldo, 1997, 119. Rabinovich, 2009. Aillón Soria, 2006, 12.

25 Francisco Manuel Costas llegó a la ciudad de Salta a mediados de la década de 1760 y se vinculó a otra familia ya asentada en la región desde principios del siglo XVIII, los Ruiz Gauna. Su matrimonio lo incorporó a esta red familiar que si bien no formaba parte del sector más tradicional de la elite salteña, se encontraba vinculada a esos sectores. Francisco M. Costas se dedicaba principalmente al comercio de efectos de Castilla, vinculándose con comerciantes locales y de Buenos Aires, con los cuales conformó redes mercantiles. A la muerte de Francisco Manuel, producida en los primeros años del siglo XIX, le sucedieron sus nueve hijos. Quiñonez, 2010 y 2012.

26 Archivo Notarial, Salta, 1825, Archivo y Biblioteca Históricos de Salta (ABHS), Carpeta 26, Protocolo 273, 141-143v.

27 Cavaleri, 1995, 23.

28 Archivo Notarial, Salta, 1825, ABHS, Carpeta 25, Protocolo 270, 63-64.

29 Archivo Notarial, Salta, 1821, ABHS, Carpeta 25, Protocolo 265, 59-60.

30 «os Peró», www.genealogiafamiliar.net [consultado: 12/05/2007]. 
revela esencial en su accionar, desprendiéndose de la red formada por su padre junto a su familia política, los Ruiz Gauna, a quienes ahora se encontraba enfrentado. ${ }^{31}$

Esta red familiar excede los límites de la ciudad y su jurisdicción. Santiago Costas luego de ordenarse sacerdote se desempeñó en la ciudad de Cochabamba ${ }^{32}$ y en tiempos de las guerras de independencia fue deán de la catedral de Potosí, mientras que Juan Manuel se casó en Abancay (provincia del Cuzco) donde se avecindó, ${ }^{33}$ en 1816 se encontraba como comandante en Tarija y a partir de 1819 se exilió definitivamente en Puno. Esta presencia y conocimiento del espacio les permitió movilizarse y seguir los avatares de la guerra como parte de las tropas realistas o exiliándose en los reductos realistas altoperuanos. Así, otros vecinos de la intendencia como Pedro Antonio Olañeta, Guillermo Marquiegui o Saturnino Castro también emigraron luego de la batalla de Salta (1813) con el ejército de Pío Tristán. ${ }^{34}$ Sin embargo, aun en tiempos de avances y triunfos de los ejércitos revolucionarios, la presencia realista en Salta se mantuvo y se articularon mecanismos para ayudar a los enrolados en la causa del rey. ${ }^{35}$ La presencia y el accionar de las mujeres constituye una clave para ahondar el estudio y la comprensión de este período. ${ }^{36}$ La historiografía local ha rescatado el accionar de algunas mujeres en la lucha contra el enemigo realista, pero también es interesante mostrar la actitud de madres y hermanas que actuaron acompañando a los jefes de las familias entre los leales a la monarquía española. Estas mujeres, que permanecieron en sus ciudades cuando los hombres partieron, son quienes continuaron con las actividades cotidianas y se hicieron cargo de distintas operaciones para mantener los negocios familiares, a la par que prestaron auxilio a las tropas realistas. Estos registros también nos permiten observar las vinculaciones existentes entre las distintas familias realistas, vínculos entretejidos a partir de las mujeres. Así, Eulalia Costas, hermana de Francisco Avelino, fue «encargada especial» en la ciudad de Salta de Josefa Marquiegui de Olañeta, ${ }^{37}$ quien permaneció en Jujuy aun cuando su marido y hermanos abandonaron la misma con los ejércitos de Pío Tristán y las

31 Quiñonez, 2007, 13. Quiñonez, 2009, 18.

32 Archivo Notarial, Salta, 1797, ABHS, Carpeta 18A, Protocolo 183, 158-159.

33 Archivo Notarial, Salta, 1805, ABHS, Carpeta 21, Protocolo 212, 57v-59.

34 Mata, 2004, 233-234.

35 Quiñonez, 2009, 18.

36 Se sigue en este apartado el análisis realizado en Quiñonez, 2007 (15-16) y 2009 (19).

37 Archivo Notarial, Salta, 1823, ABHS, Carpeta 25, Protocolo 268, 19-19v. 
siguientes retiradas del ejército realista. Por su parte, el coronel Guillermo Marquiegui figura como apoderado de María Ignacia Ruiz Gauna mientras las tropas ocupaban Salta en $1821 .{ }^{38}$ Pero estos vínculos también se expresaron en auxilio de las tropas realistas durante los últimos esfuerzos por recuperar las ciudades de Salta y Jujuy para la causa del rey. En mayo de año 1821 María Ignacia Ruiz Gauna (madre de Francisco Avelino Costas) y una de sus hijas se presentaron ante el gobernador intendente de Salta, José Ignacio Gorriti, para auxiliar al coronel Juan Guillermo Marquiegui y a su hermano, quienes se hallaban bajo arresto, y pidieron fueran trasladados a su domicilio, ya que «uno y otro se hallan gravemente heridos, a fin de proporcionarles con más comodidad los medicamentos y asistencias necesarias». ${ }^{39}$ En este auxilio a los Marquiegui, las dos mujeres no solo comprometieron su nombre sino también sus propiedades, hipotecando tres fincas de la familia, haciendo de «causa ajena suya propia». El respaldo otorgado por ambas a los Marquiegui fue significativo en tanto ambos hermanos eran reconocidos militares de los ejércitos del rey, mostrando además que no disminuyó el fervor realista de la familia Costas.

Para inicios del siglo XIX, Jaime Peire postula la construcción de una autorreferencialidad en Buenos Aires a partir de «las patrias» que fueron surgiendo. Desde el periódico Telégrafo Mercantil, se promovía una patria que coincidía con el espacio de «las Provincias del Río de la Plata, que constituían el virreinato de creación muy reciente [1776]», y aludía a «Buenos Aires y sus Provincias». En el interregno 1801-1806, este autor analiza el despliegue temático de una patria asentada en la imagen del poderío económico del Río de la Plata y por la cual Buenos Aires aparece en la construcción de procesos de identificación a partir de un espejo autocelebratorio. ${ }^{40}$ Esto implica considerar otra veta del proceso, la transición del patriotismo del antiguo régimen - donde el sentido de pertenencia estaba en el rey, la religión y el estado- hacia un patriotismo que se fue configurando desde las dos victorias obtenidas por las milicias de Buenos Aires en las invasiones inglesas de 1806 y $1807,{ }^{41}$ y que con la revolución depositó la fuente de sentido en el ejercicio de la soberanía una vez instalada la junta de gobierno en $1810 .{ }^{42}$ Esa reversión de la soberanía terminó orientándose al

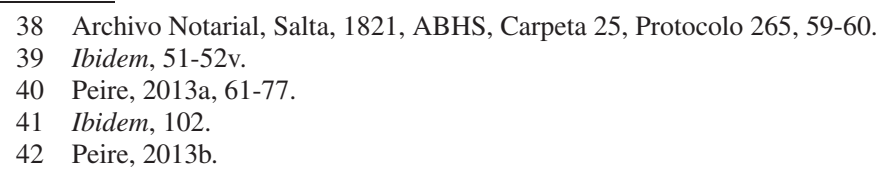


mínimo posible de cohesión política, es decir a las ciudades, como «las únicas capaces de establecer un rudimento de organización social para mantener el orden», lo que entró en tensión con las jerarquizaciones impuestas durante las reformas borbónicas. Las ciudades y sus cabildos renegaron de la dependencia de otra entidad a la que consideraban igual, por lo que ese localismo municipal suprimió «el engranaje de las intendencias [y la] subordinación de unas ciudades respecto a otras». ${ }^{43}$ Las provincias como nuevas entidades políticas fueron creadas por disposiciones de los gobiernos centrales en 1814; entre ellas se encontraban Entre Ríos y Corrientes, separadas de la intendencia de Buenos Aires; Salta y Tucumán por la división de la intendencia que tenía como ciudad cabecera a Salta. Por otra parte, algunas elites dirigentes decidieron la segregación de sus ciudades de otras de las cuales dependían. Esto sucedió con Santa Fe que se separó de Buenos Aires en 1818, Santiago del Estero en 1820 y Catamarca en 1821 de Tucumán; Jujuy de Salta en $1834 .{ }^{44}$

La conformación de la provincia suponía también una delimitación territorial, lo que acarreó conflictos durante la primera mitad del siglo XIX. Salta, establecida como provincia por un decreto del Directorio en 1814, incluía un conjunto de ciudades en disímil situación: Salta, Jujuy, Orán, Tarija y Santa María. Durante la guerra de independencia, Tarija se encontraba bajo el control de los ejércitos realistas. Orán — de reciente creación - fue la única que permaneció subordinada a Salta. Santa María, vinculada con Tucumán, nunca se encontró efectivamente unida a la provincia salteña y finalmente se mantuvo en la jurisdicción de Catamarca. ${ }^{45}$ Por su parte, el cabildo de Jujuy reclamaba estar en igualdad respecto del de Salta, lo que se hizo explícito en ocasión de la elección de gobernador en 1815 y $1818 .{ }^{46}$ Es necesario entonces entender el problema del poder y la soberanía en vinculación con la materialización de ese ejercicio de la autoridad en el territorio provincial. ${ }^{47}$ Esto se visualiza con las ciudades que dieron forma a la provincia de Salta de manera discontinua. Terminada la guerra de independencia, Tarija solo estuvo incorporada a la provincia en 1826 durante pocos meses, hasta que se unió a Bolivia, mientras que Jujuy permaneció hasta 1834.

43 Chiaramonte, 1991, 26-28.

44 Chiaramonte, 1995, 174. Goldman, 1998, 108.

45 Marchionni, 2013, 27-28. De la Vega, 1947.

46 Marchionni, 2013, 44-45.

47 Figueroa, 2000. Marchionni, 2011. 
El período abierto en 1821 dio inicio al proceso de institucionalización de Salta con la creación de las Juntas Provincial y Permanente, ${ }^{48}$ y una configuración compleja, en tanto no existió «una unidad territorial con una ciudad cabecera que haya dado origen a la Provincia a partir de la jurisdicción del Cabildo». ${ }^{49}$ Es importante tener en cuenta que la conformación de una unidad territorial, jurídica y política que expresara la existencia de la provincia de Salta no ocurrió sino hasta que Jujuy se autonomizó en $1834 .{ }^{50}$ Marchionni sostiene que en el interregno de 1820 a 1830 «las primeras referencias textuales a entidades políticas supraprovinciales como pudiera ser la nación argentina» fueron débiles, así como escasas «las adscripciones que pudieran remitir a una identidad provincial». Todo esto alerta acerca de la necesidad de pensar las construcciones identitarias y las pertenencias en vinculación con la cuestión territorial, dado que no existió una identidad única y uniforme en Salta a lo largo de la primera mitad del XIX.$^{51}$ De allí que resulte significativo prestar atención a coyunturas que pudieron actuar a manera de catalizadoras de sentidos de pertenencia, las cuales permitan indagar en los derroteros identitarios de las denominaciones argentinos, abajeños, altoperuanos y bolivianos.

\section{Salta: la frontera de las Provincias Argentinas}

La firma del armisticio en 1821 entre el jefe del ejército de vanguardia realista, el general Pedro Antonio Olañeta, y la fracción de las elites de Salta y Jujuy a través de los comisionados de los respectivos cabildos terminó con la guerra independentista en territorio salto-jujeño. El armisticio estableció el retiro de las tropas realistas al Alto Perú y el compromiso de respetar los territorios gobernados por cada fuerza, permitiendo delinear espacios políticamente diferenciados a partir de establecer como límite la

48 La Junta Provincial surgió con el armisticio de 1821, cuando se reunieron los representantes de las ciudades de Salta, Jujuy y Orán, y los respectivos curatos rurales. Se adjudicó a la Junta el carácter de depositaria de la «autoridad soberana de la Provincia» y se sancionó un Reglamento que establecía la organización de los tres poderes y la elección del gobernador. El Reglamento determinaba la creación de la Junta Permanente que recibiría la delegación de la autoridad de la Junta Provincial reunida en esos momentos con carácter constituyente y electivo. Ambas funcionaron como un poder legislativo desdoblado. Marchionni, 2013, 30-53.

49 Ibidem, 58.

50 Ibidem, 25.

51 Chiaramonte, 1989, 73. Marchionni, 2011, 15. 
quebrada de Humahuaca (mapa 1). ${ }^{52}$ La frontera política pasaba a ser objeto de interés y se volvía necesario asegurar su defensa, ${ }^{53}$ como se desprende del informe del gobernador Juan Antonio Álvarez de Arenales ${ }^{54}$ a la Legislatura provincial:

Las tropas de línea, así los Dragones que hacen el servicio de vanguardia en la Quebrada de Humahuaca, como el batallón de Cazadores de nueva creación que existe en ésta, al mando de jefes distinguidos y expertos se conservan con una moral y disciplina laudable, y el Gobierno se promete de su fidelidad, orden y bravura, no solo la defensa y seguridad de la Provincia, si tambien otros servicios de alta importancia á toda la Nacion..$^{55}$

El fin de la guerra en territorio salteño significó para las provincias altoperuanas el fin de la posibilidad de alcanzar la independencia a partir de la acción de las provincias «de abajo», ${ }^{56}$ ya que con la disolución del Directorio en Buenos Aires quedó trunco el proyecto para organizar una fuerza militar que «avanzara al Alto Perú en apoyo a la campaña de José de San Martín con el Perú». ${ }^{57}$ La guerra siguió en el Alto Perú hasta la victoria del general Antonio José de Sucre sobre los ejércitos realistas en diciembre de 1824. Mientras que en Salta, el gobernador José Ignacio Gorriti (18211823) desestimó la organización de fuerzas militares para avanzar hacia ese territorio. Debido al entendimiento posible para firmar la paz entre España y Buenos Aires, que se estaba tramitando en 1822, no prosperó el apoyo político y económico para continuar la guerra en el Alto Perú. No obstante lo establecido por el armisticio, el proyecto de liberar las provincias altoperuanas persistió entre algunos de los miembros de la elite salteña y otros actores militares que habían participado en las acciones a favor de la independencia, como los altoperuanos José María Pérez de Urdininea, Melchor Daza y Agustín Dávila. ${ }^{58}$ La desestructuración de los circuitos mercantiles provocada por la guerra tuvo un impacto diferencial en territorio

52 Figueroa, 2000, 227-230. Bragoni y Mata, 2007, 252.

53 La construcción de fronteras estatales implicó un proceso histórico específico y complejo. Estas fronteras establecen los límites del territorio sobre el cual se pretende el monopolio del ejercicio legítimo de la violencia. Grimson, 2005.

54 Peninsular de actuación destacada en la guerra de independencia, gobernador de Salta entre 1824-1827. Mata y Figueroa, 2005, 141.

55 Mensaje del Gobierno de Salta a la Cuarta Legislatura, Salta, 15 de diciembre de 1824, Archivo General de la Nación (AGN), Sala VII, Colección Celesia, Doc. 1254, 2.

56 Delimitación espacial utilizada a partir de la percepción territorial en relación al Alto Perú/ Bolivia, vigente durante el período colonial y el siglo XIX. Mata, 2005, 17.

57 Mata, 2012.

58 Figueroa, 2014. 
saltojujeño, por lo cual también los comerciantes trataron de mantener la vinculación con la economía minera. ${ }^{59}$ Los esfuerzos para liberar al Alto Perú se materializaron con dos expediciones militares que en 1825 terminaron unificadas. Una es la que preparó Pérez de Urdininea, designado jefe de la Expedición al Alto Perú por el general San Martín y para la cual comenzó a gestionar recursos en noviembre de 1822. Debido a varias dificultades, esta expedición no pudo concretarse en ese momento. ${ }^{60}$ Posteriormente, en enero de 1824 el general Sucre, jefe del Ejército Unido Libertador del Perú, remitió invitación al gobierno de Salta para participar de la campaña al Alto Perú. ${ }^{61}$ Recién en febrero de 1825 el Congreso General Constituyente reunido en Buenos Aires respondió al pedido de auxilio militar autorizando la expedición al mando del gobernador de Salta, el general Arenales. Si bien para este año convergieron sendos esfuerzos militares, solo la expedición que se encontraba bajo las órdenes de Urdininea llegó a actuar contra los realistas. ${ }^{62}$

Aun cuando las autoridades porteñas designaron al gobernador salteño « jefe de la expedición a fin de reivindicar sus derechos sobre las provincias del Alto Perú», Arenales consideró «oportuno apoyar la reunión de un Congreso que decidiera el futuro de las provincias altoperuanas» ante el temor de que se desatara la anarquía. ${ }^{63}$ También recibió instrucciones del Congreso reunido en Buenos Aires para no intervenir respecto a la decisión que tomarían los altoperuanos. ${ }^{64}$ El gobierno de Buenos Aires estaba al tanto de las intenciones independentistas de sectores de la elite altoperuana, de jefes que habían actuado en el ejército realista y de integrantes de las expediciones provenientes desde el sur; ${ }^{65}$ además en esos momentos suscitaba

59 No solo adhesiones políticas llevaron a algunos salteños a enrolarse en el bando realista, sino que los comerciantes trataban de salvar las rutas que unían al Alto Perú. Halperin Donghi, 2002, 77. De hecho el armisticio de 1821 autorizó el comercio entre Salta y las provincias altoperuanas bajo control del ejército realista. Figueroa, 2014.

60 Idem.

61 Mensaje del Gobierno a la Quinta Legislatura, Salta, 26 de Abril de 1826, AGN, Sala VII, Colección Celesia, Doc. 1260, 3. «Posta al Cóndor de Bolivia, Un Abajeño», El Cóndor de Bolivia, 10 de enero de 1826, 4. Agradecemos a Sara Mata, quien nos facilitó un ejemplar de la edición del periódico El Cóndor de Bolivia (1825-1828) hecha por la Academia Boliviana de la Historia en 1995.

62 Mata y Figueroa, 2005. Figueroa, 2014.

63 Figueroa, 2014, 13.

64 Carta de Bolívar a Santander, Potosí, 10 de octubre de 1825. O’Leary, 1887, 132-133. Figueroa, 2000, 227. Mata y Figueroa, 2005, 142-143.

65 Urdininea se encontraba en combinación con los separatistas, luego integró el gobierno boliviano. José Mariano Serrano, altoperuano y secretario de la expedición comandada por Arenales, participó de la Asamblea y más tarde presidió la Legislatura. Mata y Figueroa, 2005, 143. 





mayor preocupación la guerra inminente con el Brasil por la posesión de la Banda Oriental. La expedición de Arenales llegó cuando ya se encontraba convocada la Asamblea que resolvería el destino de los antiguos territorios de la Audiencia de Charcas, novedad que el general Sucre puso «en conocimiento de los diferentes Gobiernos de las Provincias Unidas». ${ }^{66}$

En mayo, el Congreso de Buenos Aires sancionó que las provincias altoperuanas dispongan «de su suerte», ${ }^{67}$ renunciando a ejercer la jurisdicción que había mantenido sobre esos territorios hasta antes del armisticio de 1821. ${ }^{68}$ En una misiva, Sucre escribía a Bolívar:

Dicen que el Gobierno y el partido ministerial han sostenido la independencia de estas provincias pero que el partido de oposición reclama la incorporación de ellas al Estado argentino; y que grandes debates hubo en el Congreso sobre el particular. Parece que la provincia de Buenos Aires ha calculado que no está en sus intereses la reunión de estas provincias á la República. ${ }^{69}$

Lo sancionado implicaba reconocer la autodeterminación de las provincias del Alto Perú y delimitaba un «nosotros» que hacía referencia al espacio rioplatense o argentino, con exclusión del altoperuano. Jorge Myers señala que hacia la primera mitad de la década de 1820 , los redactores del periódico El Argos de Buenos Aires reseñaban las informaciones sobre el Alto Perú en la sección «Noticias de Afuera», ${ }^{70}$ mientras que aquellas sobre «Montevideo» o la «Banda Oriental» aparecían casi siempre colocadas bajo el rubro de las «Provincias del Río de la Plata» (a pesar de su incorporación como «provincia cisplatina» al Imperio Brasileño). Conocida la independencia de Bolivia, los redactores procedieron a diferenciar al Alto Perú por su población, costumbres y permanencia de «quince años más bajo el régimen despótico español» respecto de las Provincias Unidas —especial-

66 «Nota de Sucre al gobernador de Salta», Mojo, 10 de abril de 1825, AGN, Sala VII, Colección Celesia, Doc. 1255, Boletín de la División Expedicionaria al Perú, 5.

67 El Cóndor de Bolivia (en adelante ECB), 21 de diciembre de 1825, 3.

68 Entre 1814 y 1821 el movimiento insurgente en las provincias altoperuanas mantuvo relación con el Ejército de Buenos Aires a través de la mediación de los generales Álvarez de Arenales y Martín Güemes. La subordinación de estas fuerzas supuso «para Buenos Aires conservar la legitimidad política sobre la jurisdicción territorial del ex virreinato». Mata, 2008, 198-208.

69 Carta de Sucre a Bolívar. Chuquisaca, 25 de junio de 1825. O’Leary, 1879, 267. El «partido ministerial» alude a una facción política en el Congreso, de tendencia unitaria y nucleada en torno a la figura de Bernardino Rivadavia, quien entre 1820-1824 ocupó el Ministerio de Gobierno de la provincia de Buenos Aires durante la gobernación de Martín Rodríguez. Paz, 2007, $20-24$. 2003,41

70 Entre 1821-1825 este periódico fue el medio de expresión de la élite porteña. Myers, 
mente de Buenos Aires-, las cuales en ese tiempo «se habían regenerado bajo la doble influencia de la experiencia de la libertad y del progreso de la ilustración». ${ }^{71}$ Lo decidido por el Congreso estaba a contramano de las expectativas iniciales que abrigaron el gobierno y los integrantes de la Sala de Representantes de Salta, «la incorporación de las Provincias del Alto Perú», en tanto se trataba de «Provincias hermanas». ${ }^{72}$

Las expectativas de los sectores de las elites salto-jujeñas se cimentaban también en la vinculación entre estos territorios y el Alto Perú, que se expresaban en los lazos comerciales de tradición colonial, en pautas culturales, de consumo y festividades compartidas. Así mismo, hombres y mujeres se encontraban unidos por vínculos familiares, de amistad, de paisanaje. El Alto Perú no constituía para los comerciantes y hacendados locales un alejado espacio de transacción, como para los comerciantes de Buenos Aires que tenían allí sus socios o dependientes, ${ }^{73}$ sino que era un espacio vivido y transitado por ellos mismos o por sus parientes. ${ }^{74}$ Para el caso de la familia Costas, algunos de los hijos de Avelino permanecieron luego de 1825 en la República de Bolivia y no regresaron a Salta. Pascuala Bailona Costas Frías contrajo matrimonio en 1825 en Potosí con el general Juan Gregorio Fernández y luego se estableció en Sucre ${ }^{75}$ donde nacieron sus tres hijos; Pío Nemesio Costas Frías también se radicó en Sucre donde contrajo matrimonio con Virginia Fernández Saravia; y Ángel Costas Frías contrajo matrimonio en Santa Cruz de la Sierra con Francisca Justiniano Cuellar. Por su parte, Josefa Costas Frías contrajo matrimonio en 1828 con Rafael Peró, militar realista quien luego de finalizada la guerra de independencia se avecindó en Salta. Sin embargo, en la década de 1850 el matrimonio emigró y se instaló también en Sucre junto a sus hijos. ${ }^{76} \mathrm{La}$ nueva generación nacida o radicada en Bolivia unió a veces sus destinos entre sí, pero el apellido Costas desapareció paulatinamente en la rama boliviana de la familia. Ángel Costas Frías tuvo tres hijas de su primer matrimonio —Delfina, Justa y Benita - que contrajeron matrimonio en

71 Myers, 2003, 54-55. Doc. 1254.

72 Posta al Nacional de Buenos Aires, Salta, 1825, AGN, Sala VII, Colección Celesia,

73 Distintos estudios han analizado las vinculaciones de comerciantes que desde la ciudad-puerto articulaban a través de otros comerciantes y dependientes un gran espacio comercial. Gelman, 1996.

74 Quiñonez, 2010.

75 Datos genealógicos tomados de www.genealogiafamiliar.net contrastados con escrituras del Archivo Notarial del ABHS. [Consultado: 15/01/2010].

76 Archivo Notarial, Salta, 1859, ABHS, Carpeta 37, Protocolo 354, 159-162v. 
Sucre. La mayor, Delfina Costas, se casó en 1858 con Belisario Peró Costas, su primo, hijo de Josefa Costas y Rafael Peró. El matrimonio de Delfina y Belisario se trasladó luego a Valparaíso donde nació su hijo, José Luis Peró Costas. Los hijos de Bailona Costas también contrajeron matrimonio en Sucre. Los otros hijos de Josefa Costas también se dispersaron por el espacio andino. Mariano Rafael Peró contrajo matrimonio en 1856 en Sucre con Manuela Uriburu Cabero, y Franklin Rafael Peró se radicó en Valparaíso al casarse en 1869 con Margarita Beeche Arana, hija de Evarista Arana y Gregorio Beeche, un importante comerciante salteño que luego de la coyuntura revolucionaria se radicó en Valparaíso, en el marco del «vuelco hacia el Pacífico» que realizó parte de la antigua economía colonial. ${ }^{77}$ Solo Francisco Manuel Costas Frías regresó a la ciudad de Salta, contrajo matrimonio en 1840 con Catalina Figueroa Güemes y logró conservar la vigencia del apellido en la sociedad salteña decimonónica. En la elaboración de las memorias familiares, estos procesos fueron desdibujados e incluso olvidados por los biógrafos. El «olvido» como estrategia de la memoria, incluye a los descendientes de la familia Costas que no regresaron a la ciudad de Salta y forjaron sus destinos en las vecinas repúblicas de Chile y Bolivia. Las ramas familiares de los Costas se bifurcaron en su accionar histórico y las memorias familiares también se construyeron dentro de los marcos nacionales, como señala Tristan Platt en su estudio sobre la familia Ortiz:

La ruptura entre las dos ramas, y el olvido de cada una con respecto a la otra, ilustra un proceso fundamental en la construcción de las nuevas fronteras republicanas. Pues, la construcción del Estado-Nación en el siglo XIX impuso, no menos que la construcción de una memoria compartida, el olvido colectivo como un mecanismo central en la delimitación de la nueva «nación». ${ }^{78}$

El curso de los acontecimientos en 1825 y los ánimos imperantes entre los altoperuanos respecto al rumbo político a seguir, influyeron para que las autoridades salteñas acataran lo resuelto por el Congreso; además se encontraban alineadas políticamente con Buenos Aires y se reconocían parte integrante de un espacio argentino en formación. El gentilicio argentino comenzaba a utilizarse para nominar a un territorio mayor y adherir a una identidad política argentina «de manera más amplia y general». ${ }^{79}$

77 Langer y Conti, 1991.

78 Platt, 1995, 140.

79 Mata, 2013, 55. 
La convicción de destinos separados respecto a los ex territorios altoperuanos y la de la pertenencia argentina en vinculación a una nueva condición de frontera aparecen también esbozadas en un mensaje que el gobernador Arenales dirigía a la Junta Provincial a principios de 1826:

La conclusion de la guerra del Perû ha cambiado la posición de esta Provincia [Salta]. Después de haber sido por el largo espacio de quince años el cordon sanitario contra la maligna influencia de la tirania metropolitana, el antemural donde se ha estrellado constantemente el furor de los Exercitos españoles, y el teatro sangriento en que tantas veces se hizo admirar el valor y ardimiento de sus hijos, regando con su sangre el arbol sagrado de la libertad, empieza hoy a formar la frontera de las Provincias argentinas, y el punto de contacto de las relaciones de esta con la nueva Republica de Bolivia. Esta circunstancia delicada demanda grandes consideraciones del Gobierno Nacional y de la Legislatura de la Provincia. ${ }^{80}$

La memoria acerca del sostenimiento de la guerra independentista pasó a formar parte de los elementos heroicos que distinguían a Salta y aportaban un sentido de identificación, como expresaba el gobernador al aludir a la condición de antemural para impedir el avance del ejército realista. Marchionni señala que las alusiones presentes en proclamas y escritos acerca del protagonismo de la provincia constituyen un elemento aglutinador y legitimador para las facciones que se ubicaban en el poder entre 1820-1830. ${ }^{81}$ En 1826 la memoria acerca de la guerra era destacada por un lector salteño del periódico El Cóndor de Bolivia, quien se autoindentificaba como «Un Abajeño» que respondía las opiniones allí vertidas: «Todo el mundo sabe que los abajeños desde el año diez no han pertenecido sino al pendón de la libertad en todas partes y en todas las circunstancias, y que las han sabido criar y aprovechar para proclamarla y propagarla». ${ }^{82}$ Por su parte, en la Legislatura, Arenales expresaba acerca de Salta: «una Provincia, que tiene tantos derechos para ser respetada por la bravura de sus hijos en la guerra, como por sus aptitudes para establecer la libertad civil». ${ }^{83} \mathrm{Hacia}$ el exterior, teniendo como interlocutores a editores y lectores del periódico boliviano, y hacia el interior de la misma provincia, con los representantes de la Junta, se recuperaba la lucha por la libertad durante la guerra como una marca identitaria de Salta. De allí las expresiones acerca de que

80 Mensaje del Gobierno a la Quinta Legislatura, Salta, 26 de Abril de 1826, AGN, Sala VII, Colección Celesia, Doc. 1260, 2

81 Marchionni, 2011, 35-37.

82 «Posta al Cóndor de Bolivia, Un Abajeño», ECB, 10 de enero de 1826, 6.

83 Mensaje del Gobierno a la Quinta Legislatura, Salta, 26 de Abril de 1826, AGN, Sala VII, Colección Celesia, Doc. 1260, 1. 
la provincia sostuvo la guerra de la independencia «con valor y ardimiento de sus hijos» y que a partir de la conformación de la República de Bolivia le correspondía la función de defender esa frontera que tenía la condición de nacional.

\section{Bolivia y la República Arjentina: la construcción de las diferencias}

Esther Aillón Soria postula que «la experiencia de las expediciones porteñas» durante la guerra de independencia «marcó una diferenciación colectiva en la identidad de los altoperuanos, moviéndolos hacia un imaginario de autonomía respecto de un Virreinato del Perú (realista) y de una presión porteña (patriota pero inefectiva)». ${ }^{84}$ Después de la declaración de la independencia por parte de la Asamblea en agosto de 1825, se construía discursivamente esa diferenciación que afirmaba el ejercicio soberano respecto de la jurisdicción de los gobiernos de Buenos Aires. ${ }^{85}$ Esto puede observarse en el periódico El Cóndor de Bolivia, ${ }^{86}$ con un tratamiento continuado en el apartado titulado «Asamblea jeneral» en siete ejemplares impresos entre diciembre de 1825 y febrero de 1826. En uno de esos apartados, los editores expusieron las razones que motivaron el pronunciamiento de la independencia, ponerse «á cubierto de las pretensiones del gobierno Arjentino», pues manifestaron que a pesar de la ley del Congreso por la cual el «Gobierno de Buenos Aires se mostró dezinteresado», «comunicó secretas instrucciones que la desmienten» ${ }^{87} \mathrm{El}$ nombre de Argentina aparecía en las páginas del periódico en referencia al gobierno de Buenos Aires. Se lo utilizaba también en relación a las otras provincias, con la denominación «Repùblica Arjentina» para aludir al conjunto de ellas. ${ }^{88}$

84 Aillón Soria, 2006, 13-14.

85 La prensa difundió el nombre Bolivia, sobre todo desde el primer número del periódico El Cóndor de Bolivia. Unzueta, 2000. En honor a Simón Bolívar, la Asamblea decretó en agosto de 1825 la denominación «República de Bolívar». La Diputación Permanente que reemplazó a esta Asamblea intercalaba el nombre de Bolivia con el de Alto Perú y comenzó a usar el gentilicio de «boliviano». Desde 1826 el nombre de Bolivia se volvió definitivo. Aillón Soria, 2006, 17-22.

86 Publicado en Chuquisaca entre 1825-1828. Los periódicos tuvieron un papel constitutivo en el proceso de formación nacional en Bolivia, durante la primera mitad del siglo XIX a partir de la intervención en los debates políticos, los esfuerzos por definir los elementos que identifican con la nacionalidad y la promoción de los valores patrios, entre otros aspectos. Unzueta, 2000.

87 «Observaciones dirijidas al autor de un papel escrito en Salta con el título de Posta al Cóndor de Bolivia», Suplemento al Cóndor de Bolivia, domingo 26 de febrero de 1826, 1.

88 Mata, 2013, 55. 
En cuanto al argumento de la pertenencia al virreinato, se sostenía que no resultaba suficiente para sustentar la unión «con los pueblos de la Republica Arjentina», dado que la revolución destruyó «cuanto hicieron las leyes españolas» y «puso à los pueblos en el goce de sus derechos». ${ }^{89}$ Ante la inexistencia de una unión con los gobiernos revolucionarios o una participación representativa del Alto Perú que pudiera considerarse legítima, nada justificaba la asociación con las provincias de abajo:

Estaremos de acuerdo en el principio político de que un pueblo no puede separarse de la sociedad á la que pertenece después de pronunciada su union con toda libertad. Sostener lo contrario sería incurrir en la horrible nota de anarquistas que tanto aborrecemos. La Asamblea ha creido que la asociación se hace espresa o tácitamente: del primero modo firmado por medio de sus representantes el pacto que los liga: la constitución. Jurando, y obedeciendo estas leyes fundamentales sin resistencia. El Alto Perú de ninguna de estas maneras se unió á la Repùblica Arjentina.

Para que la carta no tenga el carácter de nulidad es indispensable que los apoderados del pueblo sean electos con legitimidad por el mismo pueblo ó sus encargados: estos son los principios ò vías legales del sistema representativo [...] Ahora bien, ¿el Alto Perù nombró Diputados para el Congreso Arjentino? Recórrase la historia de los Gobiernos de la Patria [los gobiernos revolucionarios rioplatenses] en los años once, trece y quince, ecsaminese el modo y quien hizo las elecciones y resultará su absoluta nulidad..$^{90}$

El Cóndor de Bolivia fue in crescendo en la exposición de los motivos en contra de la unión con las provincias de abajo. En referencia a las expediciones realizadas durante la guerra independentista pusieron mayor acento en que esta autodeterminación era producto del olvido y abandono generado por el gobierno «arjentino», y por la cual se disolvió la «antigua asociación» de los territorios del Alto Perú con la jurisdicción rioplatense. Dos meses después, en febrero de 1826, el periódico homologaba el «poder arjentino» al «poder español» como igualmente despóticos y opresores:

Si nuestras provincias en el largo período de la revolucion han sufrido mas que otras el despotismo, es por que pasaba alternativamente del poder español, al poder Arjentino; es por que los Ejercitos que los acompañaron por tres veces con el titulo de ausiliares, ${ }^{91}$ usaron una conducta mas opresora que los que venían de la metrópoli, es porque los mandatarios argentinos eran mas barbaros que los jefes españoles. ${ }^{92}$

$89 E C B, 14$ de diciembre de $1825,2$.

$90 E C B, 14$ de diciembre de $1825,3$.

91 Refiere a las expediciones que realizó el Ejército Auxiliar en el Alto Perú entre 1811 y 1815.

92 «Observaciones dirijidas al autor de un papel escrito en Salta con el titulo de Posta al Cóndor de Bolivia», Suplemento al Cóndor de Bolivia, 26 de febrero de 1826, 1-3. 
La identificación «actúa a través de la diferencia, entraña un trabajo discursivo, la marcación y ratificación de límites simbólicos [...]. Necesita lo que queda afuera, su exterior constitutivo, para consolidar el proceso». ${ }^{93}$ De allí que aparecieran artículos que aludían a la situación de las «provincias de abajo», sumidas en la anarquía por la disolución del gobierno central. Los editores consideraban que esto había puesto al Alto Perú «en plena libertad de disponer de su suerte». ${ }^{94}$ Esa falta de organización «bajo un sistema de unidad» era un inconveniente para unirse a «la Republica Arjentina»:

Cuando por consecuencia de estos acontecimientos las miserables rancherías de Santa Fe, Rioja, Catamarca, Santiago, cada uno de estos pueblos con trescientas cuatrocientas almas y las provincias de Córdoba y Salta ejercen su plena soberania cuando el Congreso instalado el año veinte y cuatro á principios no ha podido organizar el Gobierno, y cuando es necesario consultar las lejislaturas parciales solo la forma que debe adoptarse en el Rio de la Plata, es claro que la asociación antigua se disolvió de tal manera que hoy mismo subsiste dislocada, y por consiguiente si alguna vez los peruanos formaron el pacto de familia sus obligaciones cesaron por la injusticia del Gobierno Arjentino, su olvido para auxiliarnos, su cesión temporal á los españoles, su absoluta impotencia, y la anarquía de la República que dura todavía. ${ }^{95}$

Las situaciones políticas divergentes brindaban los argumentos para construir las diferencias entre las provincias argentinas y Bolivia, operación discursiva en la que los opuestos anarquía/orden obtenían centralidad, haciendo temer «que la anarquía pasase los limites del suelo argentino [...] a perturbar la paz de los Bolivianos», quienes habían iniciado un proceso de institucionalización y organización administrativa ${ }^{96}$ que era leído como bien supremo frente a la dispersión del «sistema federal» adoptado por la Argentina, a partir de la inexistencia de un gobierno central y la organización autónoma de las provincias:

Nosotros no deseamos la abyección y la ruina de la Republica Arjentina: nosotros quisiéramos que ella, prosperè á la par de los demás Estados libres de América, que olvide la ecsaltacion de sus ideas, que abandone para siempre el sistema federal cuyas funestas consecuencias ha experimentado ya con bastante destrucción de su

93 Hall, 2003, 17.

$94 E C B, 21$ de diciembre de $1825,3$.

95 Idem.

96 La Asamblea General declaró la forma de gobierno representativa, republicana y de régimen unitario y creó los símbolos nacionales (bandera, moneda, escudo). En 1826 la Asamblea Constituyente sancionó la constitución. Aillón Soria, 2006, 19-21. 
tranquilidad y de su crédito, que forme con nosotros los sagrados vinculos del interés común, que se penetre de los sentimientos liberales del siglo, y que por fin marche con los demás pueblos á la opulencia y á la gloria que se preparan para nuestro continente: que ponga al frente de sus negocios hombres de ilustración y de virtud; y que una vez entregada su confianza sepa respetar la estabilidad de las autoridades que la presiden: sobre todo que imite nuestra conducta, que siga nuestros pasos, persuadiéndose que por esta senda se encamina á la prosperidad y el honor. ${ }^{97}$

La divisoria nosotros/ellos, es decir: Bolivia/República Argentina-Provincias argentinas, no agotaba la dinámica de las identificaciones. Esto se observa al considerar cómo visualizaba el periódico a algunas provincias, apareciendo ambivalencias en los discursos ${ }^{98}$ El periódico El Pregón de $S a l t a^{99}$ en mayo de 1826 elogió a Bolivia y sus autoridades, actitud que fue retribuida por el periódico boliviano en el reconocimiento de la participación de la provincia en la guerra de independencia:

nos es tanto mas estimable cuanto que viene como el sentimiento de una provincia Arjentina que, sola y abandonada á sus propias fuerzas después del año 15, no vaciló en hacer frente á las tropas realistas para defender su libertad y el transito de los enemigos á aquella Republica. Salta ocupa un lugar muy distinguido en la guerra de la revolucion por el patriotismo con que sus hijos prefirieron la muerte antes que permitir en su suelo las lejiones españolas. Nos es muy agradable_este tributo a una de las provincias de las mas beneméritas en la Republica Arjentina, y que, siendo fronteriza de Bolivia, tendrá siempre nuestra amistad y nuestros votos por su bien y dicha. ${ }^{100}$

Estas expresiones reflejan también una realidad sobre las vinculaciones entre los distintos espacios y territorios y el impacto de los procesos abiertos con la revolución de 1810. Las decisiones tomadas en Buenos Aires o por los distintos Congresos no siempre representaban los intereses de los altoperuanos ni los de la provincia de Salta. La guerra de independencia implicó una acción directa de sus hombres — reconocida como «patriotismo»- $\mathrm{y}$ un impacto sobre la población, la producción y el comercio. La característica de mayor impacto de este proceso es que los centros mineros andinos quedaron en manos realistas hasta 1825 y luego pasaron a formar parte de la República de Bolivia, desestructurando rutas comerciales,

97 «Observaciones dirijidas al autor de un papel escrito en Salta con el titulo de Posta al Cóndor de Bolivia», Suplemento al Cóndor de Bolivia, 26 de febrero de 1826, 3.

98 Los editores conocían lo que pasaba en las provincias argentinas por los periódicos procedentes desde allí, y la presencia de emigrados políticos. «Correo Nacional», $E C B, 16$ de noviembre de 1826,1 .

99 Periódico publicado entre mayo y noviembre de 1826. Zinny, 1868, 286.

100 «Periódicos Arjentinos», ECB, 34, 30 de julio 1826, 3. 
relaciones familiares, vínculos y trayectorias de raigambre colonial. ${ }^{101}$ Las redes de poder fueron alteradas desde el inicio de la revolución y las elites locales fueron interpeladas y reconfiguradas en estas décadas. Los grupos familiares se vieron incluso fracturados. La pertenencia a los sectores realistas llevó a muchos miembros de las familias de elite a seguir los derroteros de los ejércitos del rey sin regresar nunca a la ciudad de Salta, como vimos. Estos lazos se vieron atravesados por las nuevas fronteras estatales, y con ello la identificación y construcción de memorias colectivas que afianzaron pertenencias territoriales en clave de los nuevos estados nacientes a la par que olvidaron trayectorias anteriores.

A pesar de estos vínculos, y si bien Salta era un provincia considerada benemérita, en la construcción de las diferencias no podía obviarse que también formaba parte de «esa tierra malhadada», donde «los papeles hablan tanto de libertad [...] en Buenos Ayres mismo altos funcionarios por decreto del gobierno sin formula judicial, y en otras provincias, militares de alto grado son fusilados y asesinados por la simple orden de un gobernador». ${ }^{102}$ La incorporación de Tarija a Bolivia en septiembre de 1826 marcó otro punto de inflexión que hizo aparecer nuevamente en las páginas de El Cóndor las referencias a los contrastes entre Bolivia y la República Argentina acerca de las situaciones políticas disímiles en lo que hacía a la elección del presidente, al reconocimiento de su autoridad, al respeto del gobierno por las libertades públicas. ${ }^{103}$ Las rivalidades y los desacuerdos existentes entre el gobierno de Buenos Aires y las otras provincias respecto a la organización de un estado unificado, marcaban una heterogeneidad que no escapaba a los editores de El Cóndor, quienes señalaban en cuanto a Buenos Aires: «Tiempo hace que sus provincias se encuentran irritadas por la prepotencia que la ciudad trata de ejercer sobre los demás pueblos». ${ }^{104}$ Contrastaba esta visión con el apoyo del gobernador Arenales y parte de la elite salteña a la política de Bernardino Rivadavia en Buenos Aires y a su proyecto de sancionar una forma de gobierno de unidad con el centro en esta provincia. ${ }^{105}$

Otro punto de ambivalencia surgía al recurrir a la noción de «pueblos hermanos» para hablar de la relación entre Bolivia y la República Argenti-

101 Assadourian y Palomeque, 2003, 200.

102 «Periódicos Arjentinos», ECB, 30 de julio 1826, 4.

$103 E C B, 13$ de julio de $1826,3$.

104 «El Duende de Buenos Ayres», ECB, 5 de noviembre de 1826, 1.

105 Di Pasquale, 2009, 224. 
na, producto de la condición de americanos, la cual implicaba amistad, paz y unión; ${ }^{106}$ armonía que los bolivianos veían descomponerse por acción del Congreso argentino «dominado por la fuerza ò facción de Buenos Ayres». ${ }^{107}$ El Cóndor también señalaba que los periódicos argentinos (El Argos de Buenos Aires, El Mensajero Arjentino, El Duende de Buenos Aires, El Pregón de Salta) y los papeles ministeriales abundaban en insultos a Bolivia: ${ }^{108}$

eran los Peruanos y Bolivianos llamados indios, brutos, estúpidos y animales; aun después se han cansado los papeles de Buenos Ayres de injuriarnos con los nombres de abyectos y serviles: siempre nosotros les hemos dicho que nuestro deseo era la paz y la unión; que entre pueblos hermanos no deben haber diferencias que no puedan cortarse amigablemente $[\ldots]^{109}$

observaremos si al Sr. Oro [Domingo de Oro, mendocino] [...] que mientras tubo esperanzas de comprometer a nuestro país de un modo activo en la guerra con el Brasil, nos hizo cumplimientos y nos llamó Bolivianos. Cuando ya no hay aquella esperanza, somos otra vez Alto Peruanos: y esto ¿por que? Por que hay miras para cuando se desembarasen de la guerra con el Brasil de llamarnos rebeldes, insurgentes, anarquistas \& c. \&c. y esto ¿por que? Por que o doblamos nuestra cerviz a Buenos Aires por que dejamos de ser collas y colonos de los porteños; por el imperdonable crimen de haber preservado nuestra Patria de los trastornos y de la anarquia: porque en medio de que somos abiectos y serviles, como nos tratan los ministeriales de Buenos Ayres, no permitimos que una facción de las orillas del plata decida de nuestros destinos, nos dé magistrados elejidos furtivamente y sostenidos por la fuerza de las provincias mismas que obedecen. ${ }^{110}$

Los editores del periódico reproducían la condición despectiva que tenía la denominación colla como referente de la población indígena. Los collas han sido identificados con los pobladores de la puna y del desierto de Atacama. Habitaban también los valles circumpuneños, en un espacio que estaba unido y articulado por «lazos socio históricos» y los cuales preexistían a las fronteras nacionales. ${ }^{111}$ De nominar a la población «de las tierras altas», el etnónimo colla "pasó a ser sinónimo de "indio", y se constituyó lentamente en una categoría de diferenciación con la sociedad no indígena». ${ }^{12}$ La connotación negativa de las denominaciones indios y collas se observa en las citas documentales. Peruanos y bolivianos aparecen con la

106 «Nota», $E C B, 12$ de noviembre de 1825, 6. «Duende y Mensajero», $E C B, 7$ de diciembre de 1826,2 .

$107 E C B, 5$ noviembre de $1826,4$.

108 «Periódicos Arjentinos», ECB, 30 de julio 1826, 3.

109 «Duende y Mensajero», $E C B, 7$ de diciembre de 1826, 1.

$110 E C B, 4$ de enero de $1826,1$.

111 Molina Otarola, 2010, 116-118.

112 Ibidem, 106. 
condición de indios, asignada por «los papeles de Buenos Aires» y calificados como brutos, estúpidos, animales, abyectos y serviles. Incluso la denominación de collas se encuentra en la correspondencia oficial durante la guerra de independencia al mencionar a las fuerzas del ejército real integradas por indígenas. Si bien los editores usan esta clasificación para justificar la decisión de conformar un estado independiente de Buenos Aires, lo que se evidencia en la mención «colonos de los porteños» como indicativo de la dependencia del Alto Perú respecto a la jurisdicción del virreinato rioplatense durante el periodo finicolonial, la atribución de inferioridad a los indígenas también era compartida por la elite boliviana. Los editores asumían la denominación de indios y collas aplicada a los bolivianos como agraviante, por lo que dejar de ser collas era dejar de ser indios por la acción de un estado organizado, de lo cual carecían los territorios de «las orillas del plata», de quienes no querían volver a depender. De hecho la historiografía acerca del proceso de construcción del estado nacional en Bolivia ha postulado «que la identidad nacional boliviana se forja en oposición a lo indígena». ${ }^{113}$ La elite independentista que asumió el poder buscó asimilar al indígena «a condición de que [...] dejara de serlo y se convirtiera en ciudadano o campesino mestizo». ${ }^{114}$

Las diferencias también se construían desde Salta a partir de la contribución a la guerra de independencia y de la obtención de la libertad por esfuerzos propios, acciones que no desarrollaron los altoperuanos. En respuesta a las expresiones que aparecían en un artículo sobre la Asamblea General, el diario boliviano recibió una carta a principios de 1826. Su autor, si bien menciona ser «un pobre gaucho que no estoi en los secretos de Gavinete», otorgaba datos acerca de la organización de la expedición que comandó Arenales y que permiten inferir que se trataba de alguien vinculado a la administración provincial:

nosotros hemos sabido ser libres y llevar la libertad a todas partes con inmensos sacrificios. ¿De donde viene la culata de la revolucion a insultar tan engreída a los biejos y constantes campeones de la libertad ¿Por qué no se aisla dentro del circulo posivo que ha ocupado siempre mientras nosotros hemos llenado el Continente de nuestro heroísmo y de nuestra sangre? ¡Que orgullo tengo al decirlo atestandolo con todo el globo! Si nuestros Pueblos son miserables rancherías como Vd. les llama; calcule qualquiera que tenga frente de quanto serán capaces estos pechos que sin la menor cooperación estraña han podido hacer tanto, y por quantos valdra cada uno de ellos- no tendría Vd.

113 Wahren, 2014, 11.

114 Cruz Rodríguez, 2012, 71. 
por cierto tamaña arrogancia si no se viese bajo la egide del Libertador Bolivar que por un hallazgo ha querido ejercitar la generosidad de su genio extraordinario entre hombres que bien pronto le harán conocer qúe como no han podido darse su libertad, tampoco han querido recibirla. De hay resulta la saña y oposición que han encontrado siempre nuestros Exercitos quando la han conducido en sus bayonetas y en sus corazones al alto Perû. ${ }^{115}$

\section{Conclusión}

La culminación de la guerra de independencia en el espacio surandino a fines de 1824 implicó la demarcación de una frontera política entre los territorios altoperuanos y aquellos ubicados al sur. Esta diferenciación había comenzado a delinearse en 1821 con el armisticio firmado entre el general Olañeta y fracciones de las elites salto-jujeñas. No obstante lo establecido en el tratado en cuanto a respetar los territorios controlados por cada fuerza, sectores de estas elites no habían renunciado a terminar con el dominio realista en el Alto Perú acompañando esfuerzos realizados desde otros territorios. La campaña finalmente se concretó a partir del despliegue de las fuerzas colombianas comandadas por el general Sucre. A pesar de las dificultades de la provincia de Salta para participar activamente se organizaron por separado dos expediciones que arribaron después del triunfo obtenido en Ayacucho por las fuerzas del Ejército Libertador Colombiano, asistiendo a la sucesión de hechos que aceleraron la decisión autonomista consolidada en la formación del nuevo estado de Bolivia en 1825. Ni el Congreso reunido en Buenos Aires, ni el gobernador Arenales de Salta, fueron ajenos a esta determinación de dejar en libertad de acción a los altoperuanos. Se abría a partir de allí el camino hacia la construcción de las diferencias.

Los derroteros disímiles entre comunidades que integraron una misma jurisdicción hasta los inicios de la guerra independentista, que mantuvieron vinculaciones de variada índole durante la etapa colonial y no completamente interrumpidas con el inicio de la revolución, llevaron a demarcar la frontera entre dos comunidades políticas con distintos rangos de organización. El reconocimiento de soberanías diferenciadas implicó también procesos de nominaciones (Bolivia, Provincias Argentinas/República Argentina) y construcciones identitarias que expresaran esas alteridades. Nos referimos a aquellas que remitían a comunidades ampliadas, como los gentilicios

115 «Posta al Cóndor de Bolivia, Un Abajeño», ECB, 10 de enero de 1826, 3. 
altoperuanos, bolivianos, argentinos; y a las expresiones que evidenciaban una referencialidad restringida a la provincia, tal es el caso de «los hijos» de Salta, o a una región, como parece denotar la expresión abajeños. Se trata de «identidades transitorias» $\mathrm{o}$ «en tránsito» — para utilizar las expresiones de Aillón Soria y Peire, respectivamente, en relación a Bolivia y al Río de la Plata-, características de un momento clave en la configuración de fronteras estatales y que adquirieron el carácter de excluyentes (altoperuanos y abajeños e hijos de Salta, argentinos y bolivianos) en tanto remitían a diferencias producidas «entre un orden interioridad-pertenencia y uno de exterioridad-exclusión». ${ }^{116}$ Estas identificaciones relacionales eran el resultado de tensiones en la coyuntura de conformación de la frontera política y de la necesidad de diferenciar espacios y poblaciones unidos por lazos comerciales, pautas culturales, vínculos familiares y de amistad. Para nada fijas, sino en proceso de redefinición y en coexistencia, es posible concebirlas en transición hasta la consolidación de las identidades nacionales boliviana y argentina en el transcurso de los siglos XIX y XX.

Fue la exaltación de las diferencias — históricas y más recientes en torno al desempeño en la guerra de independencia y a la forma de organización política adoptada - entre dos constructos «República Argentina» y «Bolivia», uno de los derroteros posibles en las construcciones identitarias y de pertenencias. En ese proceso, la provincia de Salta tuvo un papel central, en tanto se constituyó en frontera entre esos dos estados en construcción. En ese contexto es posible observar elaboraciones discursivas desde Salta y desde Bolivia respecto a realidades que distinguían a una y otra organización, y que referían en tono aglutinante, a las antiguas Provincias Unidas, ahora identificadas como República Argentina. Pero justamente la década de 1820 fue una coyuntura donde esta conformación distó de realizarse. Las provincias argentinas soberanas realizaban su propio proceso de establecer rasgos identificatorios, pero también de ejercer el poder en un territorio aun con límites difusos. En el caso de Salta se observa este esfuerzo y una disputa que recién fue saldada en 1834 con la separación de Jujuy.

Entre el constructo de dos estados/naciones/territorios quedó la provincia de Salta, anclada en los Andes meridionales, con fuertes vínculos culturales con las provincias de arriba, pero también reconociendo y enrolándose sus hombres en las guerras iniciadas a partir de 1810 y formando parte de las «Provincias Unidas». El enemigo común —el rey o los insurgentes,

116 Restrepo, 2007, 25. 
según el caso- que durante el decenio de 1810 aunó voluntades, en la década siguiente y con la finalización de la guerra a partir de 1824, se reformuló de manera tal que posibilitaba nuevas formas de diferenciación ancladas en la pertenencia a alteridades recientes como lo eran las provincias argentinas y Bolivia, que bregaban por afirmar soberanías sobre los territorios que reivindicaban como propios en tanto los unían o separaban devenires históricos y trayectorias políticas. Plantea Eduardo Restrepo que las identidades ponen en juego prácticas de asignación y de identificación, al tiempo que requieren ser asumidas por los individuos o colectivos que se reconocen en ellas, aunque sea de manera parcial. ${ }^{117}$ En este contexto, «los hijos» de Salta se distinguían por la bravura en la lucha y la propagación de la libertad durante la guerra de la independencia, rasgos y acciones mediante los cuales se constituían discursivamente tanto Arenales ante la Sala de Representantes como aquel lector anónimo del periódico El Cóndor de Bolivia. Por su parte en Bolivia, el periódico vocero de la administración de Sucre insistía en la ruptura de la asociación del Alto Perú con los gobiernos revolucionarios, una asociación que con la contienda independentista ya finalizada se consideraba inconveniente dada la «anarquía» imperante en las provincias argentinas por la ausencia de un gobierno centralizado. Mientras que Bolivia transitaba el camino de una organización estatal acelerada, la provincia de Salta, también internamente en proceso de institucionalización, se convirtió en el límite político entre dos estados en formación, perdiendo el rol de ciudad intermediaria que detentaba en el período colonial.

Recibido el 5 de mayo de 2015 Segunda versión el 30 de abril de 2016 Aceptado el 13 de mayo de 2016

\section{Referencias bibliográficas}

Aillón Soria, Esther, «De Charcas/Alto Perú a la República de Bolívar, Bolivia. Trayectorias de la identidad boliviana», Coloquio Internacional Creando la Nación. Los nombres de los países de América Latina: Identidades políticas y nacionalismo, México, 2006, http://shial.colmex.mx/textos/EstherAyllon. pdf [Consultado: 02/04/2015].

Amadori, Arrigo y Di Pasquale, Mariano, «Introducción. Identidades y sentimientos de pertenencia en el espacio rioplatense: miradas históricas entre la colonia

117 Restrepo, 2007, 28-29. 
y el período independiente», en Amadori, A. y Di Pasquale, M. (coords.), Construcciones identitarias en el Río de la Plata, Siglos XVIII-XX, Rosario, Prohistoria, 2013, 11-22.

Assadourian, Carlos y Palomeque, Silvia, «Las relaciones mercantiles de Córdoba (1800-1830). Desarticulación y desmonetización del mercado interno colonial en el nacimiento del espacio económico nacional», en Irigoin, Alejandra y Schmit, Roberto (eds.), La desintegración de la economía colonial. Comercio y moneda en el interior del espacio colonial (1800-1860), Buenos Aires, Biblos, 2003, 151-225.

Bragoni, Beatriz y Mata de López, Sara, «Militarización e identidades políticas en la revolución rioplatense», Anuario de Estudios Americanos, 64-1, Sevilla, 2007, 221-256.

Briones, Claudia: «Teorías performativas de la identidad y performatividad de las teorías», Tabula Rasa, 6, Bogotá, 2007, 55-83.

Cavaleri, Paulo, «Los realistas de Salta», Revista Todo es Historia, 337, Buenos Aires, 1995, 20-31.

Chiaramonte, José Carlos, «Formas de identidad en el Río de la Plata luego de 1810», Boletín Ravignani, 1, Buenos Aires, 1989, 71-92.

Chiaramonte, José Carlos, «La cuestión regional en el proceso de gestación del estado nacional argentino», en Chiaramonte, J. C., Mercaderes del Litoral. Economía y sociedad en la provincia de Corrientes, primera mitad del siglo XIX, Buenos Aires, FCE, 1991, 21-54.

Chiaramonte, José Carlos, «¿Provincias o Estados?: Los orígenes del federalismo rioplatense», en Guerra, François-Xavier (dir.), Las revoluciones hispánicas: independencias americanas y liberalismo español, Madrid, Editorial Complutense, 1995, 167-206.

Conti, Viviana, «La frontera argentino-boliviana durante la temprana República. Complementariedad económica e integración social», Si somos americanos. Revista de Estudios Trasandinos, 1, 1, Santiago de Chile, 2011, 13-40.

Cruz Rodríguez, Edwin, «Identidades indígenas y etnonacionalismo en los Andes. Los casos de Bolivia y Ecuador», Revista de Historia Comparada, 6, 2, Río de Janeiro, 2012, 68-111.

De la Vega, Alfonso, «Catamarca (1810-1862)», en Levene, Ricardo (dir.), Historia de la Nación Argentina (Desde los orígenes hasta la organización definitiva, en 1862), vol. X, Academia Nacional de la Historia, Buenos Aires, 1947, 280-319.

Di Pasquale, Mariano, «La gestión de Álvarez de Arenales en Salta. Presencia del rivadianismo en Salta (1824-1827)», Revista Complutense de Historia de América, 35, Madrid, 2009, 209-231.

Figueroa Solá, Eulalia, «Los límites del poder. Territorialidad y soberanía», en Mata, Sara (coord.), Persistencias y cambios: Salta y el Noroeste Argentino. 1770-1840, Rosario, Prohistoria, 2000, 219-239. 
Figueroa Solá, Eulalia: «Conflictos políticos y negocios. La última expedición rioplatense al Alto Perú», Revista Andes, Salta, 2014, http://www.redalyc.org/ articulo.oa?id=12738569001 [Consultado: 04/04/2015].

Gelman, Jorge Daniel, De mercachifle a gran comerciante: los caminos del ascenso en el Río de la Plata Colonial, La Rábida (Huelva), Universidad Internacional de Andalucía, 1996.

Goldman, Noemí, «Crisis imperial, Revolución y guerra (1806-1820)» y «Los orígenes del federalismo rioplatense (1820-1830)», en Goldman, Noemí (dir.), Nueva historia argentina, Buenos Aires, Sudamericana, 1998, 21-69 y 103124 , respectivamente.

Goldman, Noemí y Souto, Norma, «De los usos de los conceptos de "nación” y la formación del espacio político en el Río de la Plata (1810-1827)», Secuencia, nueva época, 37, México, 1997, 35-56.

González Bernaldo, Pilar, «La "identidad nacional” en el Río de la Plata post-colonial. Continuidades y rupturas con el Antiguo Régimen», Anuario del IEHS, 12, Tandil, 1997, 109-122.

Grimson, Alejandro, «Fronteras, estados e identificaciones en el Cono Sur», en Mato, Daniel (comp.), Cultura, política y sociedad. Perspectivas latinoamericanas (antología), Buenos Aires, CLACSO, 2005, 127-142, http:// bibliotecavirtual.clacso.org.ar/ar/libros/grupos/mato/Grimson.rtf [Consultado: 02/04/2015].

Guerra, François-Xavier, «Identidad y soberanía: una relación compleja», en Guerra, François-Xavier (dir.), Las revoluciones hispánicas: independencias americanas y liberalismo español, Madrid, Editorial Complutense, 1995, 207-239.

Hall, Stuart, «¿Quién necesita identidad?», en Hall, Stuart y Du Gay, Paul (comps.), Cuestiones de identidad cultural, Buenos Aires, Amorrortu, 2003, 13-39.

Halperin Donghi, Tulio, Revolución y guerra. Formación de una elite dirigente en la Argentina criolla, Buenos Aires, Siglo XXI, 2002.

Langer, Erick y Viviana Conti, «Circuitos comerciales tradicionales y cambio económico en los Andes Centromeridionales (1830-1930)», Revista Desarrollo Económico, 31, 121, Buenos Aires, 1991, 91-111.

Marchionni, Marcelo, El poder político en Salta a fines del período colonial, Tesis de licenciatura, inédita, Universidad Nacional de Salta, 1997.

Marchionni, Marcelo, «Una elite consolidada. El Cabildo de Salta en tiempos de cambios», en Mata de López, Sara (comp.), Persistencias y cambios: Salta y el Noroeste argentino. 1770-1840, Rosario, Prohistoria y Manuel Suárez editor, 1999, 177-217.

Marchionni, Marcelo, «La formación de la provincia de Salta. Entre la integración territorial y la construcción político-identitaria (1820-1830)», en Mata de López, Sara y Palermo, Zulma (comps.), Travesía discursiva: representaciones identitarias en Salta (siglos XVIII-XIX), Rosario, Prohistoria, 2011, 13-40. 
Marchionni, Marcelo, Política y sociedad en Salta y el norte argentino (17801850), Tesis doctoral, inédita, Universidad Nacional de Salta, 2013.

Mata de López, Sara, «Los comerciantes de Salta a fines del siglo XVIII», Anuario Escuela de Historia, 16, Universidad Nacional de Rosario, 1993, 189-210.

Mata de López, Sara, «El noroeste argentino y el espacio andino en las primeras décadas del siglo XIX», en Fernández, Sandra y Dalla Corte, Gabriela (comps.), Lugares para la Historia. Espacio, historia regional e historia local en los estudios contemporáneos, Hamburgo, Rosario, UNR Editora, 2001, 137-156.

Mata de López, Sara, «Salta y la guerra de independencia en los Andes Meridionales», Jahrbuch Für Geschichte Lateinamerikas, 41, Hamburgo, 2004, 223-246.

Mata de López, Sara, Tierra y poder en Salta. El noroeste argentino en vísperas de

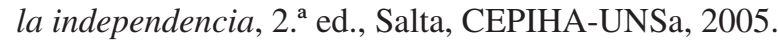

Mata de López, Sara, «Insurrección e independencia. La provincia de Salta y los Andes del Sur», en Fradkin, Raúl (ed.), ¿Y el pueblo dónde está? Contribuciones para una historia popular de la revolución de independencia en el Río de la Plata, Buenos Aires, Prometeo, 2008, 177-208.

Mata de López, Sara, «La herencia de la guerra: Salta (Argentina) 1821-1831», Nuevo Mundo Mundos Nuevos, 2012, http://nuevomundo.revues.org/63221 [Consultado: 15/03/2014].

Mata de López, Sara, «Construyendo identidades: la guerra de independencia en los Andes del Sur», en Amadori, Arrigo y Di Pasquale, Mariano (coords.), Construcciones identitarias en el Río de la Plata, Siglos XVIII-XX, Rosario, Prohistoria, 2013, 41-58.

Mata de López, Sara y Figueroa, Eulalia, «Guerra de independencia y conflicto social en Salta. Territorialidad y fronteras políticas en la construcción de los estados nacionales. 1810-1840», Cuadernos de Historia, Serie Economía y Sociedad, 7, Córdoba, 2005, 129-151.

Molina Otarola, Raúl José, Collas y atacameños en el desierto y la puna de Atacama y el valle de Fiambalá: sus relaciones transfronterizas, Tesis de doctorado, Arica, Universidad de Tarapacá, Universidad Católica del Norte, 2010, http://iiam.ucn.cl/documentacion/files/original/e6bb711437bd890ee 1f60759beelea64.pdf [Consultado: 20/03/2016].

Myers, Jorge, «Identidades porteñas. El discurso ilustrado en torno a la nación y el rol de la prensa: El Argos de Buenos Aires, 1821-1825», en Alonso, Paula (comp.), Construcciones impresas. Panfletos, diarios y revistas en la formación de los estados nacionales en América Latina, 1820-1920, Buenos Aires, FCE, 2003, 39-63.

O'Leary, Daniel Florencio, Memorias del General O'Leary, Tomo I, Correspondencia de Hombres Notables con el Libertador, Caracas, Imprenta de La Gaceta Oficial, 1879. 
O’Leary, Daniel Florencio, Memorias del General O'Leary, Tomo XXX, Cartas del Libertador, Caracas, Imprenta y Litografía del Gobierno Nacional, 1887.

Paz, Gustavo L., Las guerras civiles (1820-1827), Buenos Aires, Eudeba, 2007.

Peire, Jaime, «Patriotismo y patriotismos rioplatenses, 1767-1812», en Amadori, Arrigo y Di Pasquale, Mariano (coords.), Construcciones identitarias en el Río de la Plata, siglos XVIII-XIX, Rosario, Prohistoria Ediciones, 2013a, 60-119.

Peire, Jaime, «De la dominación "suave y dulce" a la soberanía del pueblo, 17671825», en Peire, Jaime; Di Pasquale, Mariano y Amadori, Arrigo (comps.), Ideologías, prácticas y discursos. La construcción cultural del mundo social, siglos XVII-XIX, Buenos Aires, EDUNTREF, 2013b, 23-79.

Platt, Tristan, «Historias unidas, memorias escindidas. Las empresas mineras de los hermanos Ortiz y la construcción de las elites nacionales. Salta y Potosí, 1800-1880», Revista Andes, 7, Salta, 1995, 137-220.

Quiñonez, Mercedes, «Familia y revolución. Vínculos familiares y lealtades políticas: el caso de la familia Costas», XI Jornadas Interescuelas/Departamentos de Historia, Universidad Nacional de Tucumán, 2007.

Quiñonez, Mercedes, «Familia y red social. La elite salteña en las primeras décadas del siglo XIX», X Jornadas Argentinas de Estudios de Población, Asociación de Estudios de Población de la Argentina, San Fernando del Valle de Catamarca, 2009.

Quiñonez, Mercedes, Familia y Poder. Los Patrón Costas y la conformación de la elite salteña (mediados del siglo XVIII a principios del siglo XX), Tesis doctoral, inédita, Universidad Nacional de La Plata, 2010.

Quiñonez, Mercedes, «Parentesco y paisanaje. Los comerciantes peninsulares y su incorporación a las redes de poder (Salta, segunda mitad del siglo XVIII)», en Celton, Dora e Irigoyen López, Antonio (eds.), Miradas Históricas sobre familias argentinas, Murcia, Editum, 2012, 95-127.

Rabinovich, Alejandro, «La gloria, esa plaga de nuestra pobre América del Sud», Nuevo Mundo Mundos Nuevos, 2009, http://nuevomundo.revues.org/56444 [Consultado: 07/05/2013].

Restrepo, Eduardo, «Identidades: planteamientos teóricos y sugerencias metodológicas para su estudio», Jangwa Pana, 5, Santa Marta, 2007, 24-35.

Ternavasio, Marcela, Historia de la Argentina. 1806-1852, Buenos Aires, Siglo XXI, 2009.

Unzueta, Fernando, «Periódicos y formación nacional: Bolivia en sus primeros años», Latin American Research Review, 35-2, 2000, 35-72, http://lasa2.univ. pitt.edu/LARR/prot/search/retrieve/?Vol=35\&Num=2\&Start=35 [Consultado: 20/03/2015].

Wahren, Cecilia, Raza, nación y folkore. La representación del indio en la construcción de la identidad nacional boliviana (1899-1933), Tesis de maestría, 
Buenos Aires, Universidad de San Andrés, 2014, http://repositorio.udesa. edu.ar/jspui/bitstream/10908/10829/1/\%5BP\%5D\%5BW\%5D\%20T.M.\%20 His.\%20Wahren,\%20Cecilia.pdf [Consultado: 20/03/2016].

Zinny, Antonio, Efemeridografía Argireparquiótica o sea de las Provincia Argentinas, Buenos Aires, Imprenta y Librería de Mayo, 1868. 